\title{
Pengaruh Pemberian Kesejahteraan Pegawai Dan Disiplin Kerja Terhadap Kepuasan Kerja Di Lingkungan Kantor Pelayanan Perbendaharaan Negara Padang
}

\author{
Sadri Amin 1 , Irdha Yusra2 \\ Sekolah Tinggi Ilmu Ekonomi "KBP" Padang, Indonesia ${ }^{1,2}$
}

$\square$ Corresponding Author:

Nama Penulis: Sadri Amin

E-mail: sadriamin772@gmail.com

\begin{abstract}
The purpose of this study in general is to examine the effect of providing employee welfare and work discipline on job satisfaction in the Padang State Treasury Service Office. This research method uses quantitative methods with a population of 40 people. The number of samples is the same as the number of population members so that it does not require a sampling technique. The final sample in this study was 40 employees. The analytical technique used is multiple regression analysis with the help of SPSS. The results of the study indicate that the effect of providing employee welfare, and work discipline is the main factor in determining the level of job satisfaction.
\end{abstract}

Keywords : Employee Welfare, Job Discipline, Job Satisfaction.

Abstrak: Tujuan dari penelitian ini secara umum untuk menguji pengaruh pemberian kesejahteraan pegawai dan disiplin kerja terhadap kepuasan kerja di lingkungan Kantor Pelayanan Perbendaharaan Negara Padang. Metode penelitian ini menggunakan metode kuantitatif dengan jumlah populasi sebanyak 40 orang. Jumlah sampelnya sama dengan jumlah anggota populasi sehingga tidak memerlukan Teknik sampling. Sampel akhir dalam penelitian ini adalah sebanyak 40 orang pegawai. Teknik analisis yang digunakan adalah Analisis regresi berganda dengan bantuan SPSS. Hasil penelitian menunjukan bahwa pengaruh pemberian kesejahteraan pegawai, dan disiplin kerja menjadi faktor utama dalam menentukan tinggi rendahnya kepuasan kerja.

Kata Kunci : Kesejahteraan Pegawai, Disiplin Kerja, Kepuasan Kerja 


\section{PENDAHULUAN}

Manajemen sumber daya manusia merupakan suatu strategi dalam melaksanakan fungsi-fungsi manjemen merupakan Perencanaan, pengorganisasian, memimpin dan mengontrol pada setiap tindakan atau pekerjaan operasional, mulai dari strategi pendaftaran, seleksi, pelatihan serta pengembangan dari sumber daya manusia bertujuan agar bertambah efektif dan efesien.

Kepuasan kerja menurut Lantara \& Utama (2014) adalah kondisi amarah yang menyenangkan ataupun tidak menyenangkan oleh pegawai dalam melihat aktivitas mereka. Kepuasan pekerjaan bisa jadi merupakan bentuk sentimen seseorang seputar pekerjaannya. Pemahaman kepada kepuasan kerja mempunyai efek besar, kepuasan kerja tidak dapat dapat dipahami dari kodisi fisik pekerjan itu sendiri, akan tetapi dari sisi non fisik.

Berdasarkan pengamatan penulis di kantor Pelayanan Perbendaharaan Negara Padang masih terdapat permasalahan terkait dengan kepuasan kerja diantaranya: Tidak semua pegawai mendapatkan kesempatan perjalanan dinas, Tidak semua pegawai mendapatkan beasiswa untuk melanjutkan jenjang pendidikan yang lebih tinggi.

Para pegawai dengan jabatan tinggi mendapat nilai kesejahteraan pegawai yang jauh lebih besar akan cendrung mendapatkan kepuasan kerja yang semakin besar. Kasus yang terjadi pada disiplin kerja benar-benar menjadi prasyarat untuk mendapatkan tunjangan. Struktur jabatan lebih tinggi dari pada kehadiran sudah semestinya bagi setiap pegawai. Kenyataan seperti ini akan memunculkan kepuasan yang berbeda dari pegwai yang mempunyai jabatan dengan pegawai yang tidak mempunyai jabatan.

Pegawai yang mendapatkan kesejahteraan pegawai yang kecil kepuasan kerjanya berkuarang. Almeida \& Perera (2015) menyimpulkan adanya korelasi positif antara fasilitas Kesejahteraan dengan Kepuasan Kerja. Melihat kenyataan tersebut maka pemberian kesejahteraan pegawai yang berbeda tidak memiliki arti penting untuk menigkatkan kesejahteraan. Jika kepuasan kerja turun akan dikwatirkan fungsi pelayanan publik bagi organisasi akan terlambat, jalannya organisasi kurang efektif. Kesejahteraan adalah "keadaan dimana seseorang merasakan adanya ketentraman (kesejahteraan batin) dan kemakmuran (kesejahteraan lahir) (M. Busro, 2018). 
Menurut Penelitian dilakukan oleh Makutika et al, (2018) menyatakan terapat pengaruh yang positif signifikan kesejahteraan terhadap kepuasan kerja pegawai. Sedangkan menurut penelitian dilakukan oleh (Hasibuan et al., 2019) terdapat berpengaruh positif dan signifikan Kesejahteraan terhadap Kepuasan Kerja. dua penelitian diatas juga sama dengan hasil penelitian Harto et al, (2015), yang menyebutkan bahwa terjadi pengaruh yang positif dan signifikan Kesejahteraan pegawai terhadap kepuasan kerja pegawai pada PT. Techkpack Asia Demak.

Disiplin ialah gambaran pekerjaan seorang pegawai kepada tugas yang diserahkan kepada pegawai. Kedisiplinan pegawai merupakan kegiatan yang segera ditanamkan dalam terciptanya tujuan organisasi ialah tujuan operatif manajemen sumber daya manusia terpenting. Semangkin besar disiplin pegawai maka, semakin besar peluang bagi perusahaan untuk maju. "Menurut Singodimedjo (2009) disiplin merupakan "kerangka keinginan dan keinginan seseorang untuk melaksanakan dan mematuhi standar disiplin di sekitarnya”. Disiplin pekerja yang tepat dalam mencapai tujuan perusahaan, Sedangkan penurunan disiplin akan menjadi penahan dan mengarahkan pencapaian tujuan perusahaan.

Sajangbati (2013) mengutarakan disiplin kerja berpengaruh signifikan terhadap kepuasan kerja. Namun apakah sama dengan fakta yang ada di lingkungan Kantor Pelayanan Perbendaharaan Negara Padang, untuk dilakukan penelitian lebih mendalam. Semakin tinggi disiplin kerja pegawai diharapkan semakin baik dalam pelyanan publik, efektivitas organisasi tergaja, dan akan saling memberikan kepercayaan, memunculkan persaingan sehat didalam berkarir, terciptanya tujuantujuan organisasi, dan mampu meningkatkan kepuasan kerja.

Alasan utama kenapa objek penelitian dipilih pada Kantor Pelayanan Perbendaharaan Negara Padang, karena masih terdapat permasalahan terkait dengan kepuasan kerja diantaranya, Tidak semua pegawai mendapatkan kesempatan perjalanan dinas, Tidak semua pegawai mendapatkan beasiswa untuk melanjutkan jenjang pendidikan yang lebih tinggi. Dengan kedua hal tersebut maka pegawai akan mendapatkan uang tambahan diluar gaji untuk bisa memenuhi kebutuhan pegawai agar kepuasan kerja akan meningkat dan kinerja menjadi lebih baik. Sehingga penelitian ini mengambil judul: Pengaruh pemberian Kesejahteraan 
Pengaruh Pemberian Kesejahteraan Pegawai Dan Disiplin Kerja Terhadap Kepuasan Kerja Di Lingkungan Kantor Pelayanan Perbendaharaan Negara Padang

Pegawai dan Disiplin Kerja terhadap kepuasan kerja di lingkungan Kantor Pelayanan Perbendaharaan Negara Padang.

\section{Pengaruh Pemberian Kesejahteraan Pegawai Terhadap Kepuasan Kerja}

Hal ini sama dengan penelitian Makutika et al, (2018), Hasibuan et al, (2019), dan Harto et al, (2015), Pengaruh yang positif dan signifikan antara pemberian kesejahteraan pegawai terhadap kepuasan kerja. Berdasarkan beberapa terdahulu dapat disimpulkan bahwa pemberian kesejahteraan pegawai adalah balas jasa tidak langsung atau imbalan diluar gaji atau upah yang diberikan kepada pegawai dan pemberiannya tidak didasarkan kinerja pegawai tetapi berdasarkan pada keanggotaannya sebagai bagian dari organisasi yang berguna untuk memenuhi kebutuhan pegawai diluar upah/gaji.

Kesimpulan dari penelitian-penelitian sebelumnya bahwa kesejahteraan pegawai menjadi keinginan setiap orang karena dengan hidup sejahtera orang akan dapat menikmati hidupnya. Demikian juga dengan pegawai disuatu perusahaan/instansi, jika kesejahteraan pegawai itu terjamin maka akan dapat meningkatkan prestasi kerja pegawai. Kesejahteraan pegawai merupakan tunjangan diluar gaji sehingga dilihat dari bentuk indikator kesejahteraan yang bersifat ekonomis sama halnya dengan dilingkungan Kantor Pelayanan Perbendaharaan Negara Padang bahwa kesejahteraan pegawai yang diberikan merupakan tunjangan di luar gaji, hal ini sangat membantu bagi para pegawai.

Bedasarkan penjelasan diatas, hipotesis yang diajukan peneliti yang akan dibuktikan secara empiris sebagai berikut:

$\mathrm{H}_{1}$ : Pengaruh yang positif pemberian kesejahteraan pegawai terhadap kepuasan kerja

\section{Pengaruh Disiplin Kerja Terhadap Kepuasan Kerja}

Hal ini sama dengan penelitian Afianto \& Utami, (2017), Wuysang \& Tawas, (2016), Pratama et al, (2020), Pengaruh yang positif dan signifikan antara Disiplin kerja terhadap kepuasan kerja. Berdasarkan beberapa penelitian terdahulu dapat disimpulkan bahwa semakin baik disiplin kerja maka semakin tinggi kepuasan kerja pegawai, begitupun sebaliknya semakin buruk disiplin kerja maka semakin turun kepuasan pegawai terhadap pekerjaannya.

Kesimpulannya dari penelitian-penelitian sebelumnya bahwa hasil ini 
mengindikasikan bahwa meningkatnya disiplin kerja yang disebabkan oleh kehadiran pegawai yang tepat waktu, tidak pernah pulang sebelum jam kerja selesai, mampu menggunakan waktu secara efektif, bekerja dengan kualitas kerja yang baik, mengikuti prosedur dan intruksi kerja dari atasan, hadir dalam setiap rapat dan berpenampilan sopan dan berpakaian sesuai aturan yang ada maka dapat menyebabkan keputusan kerja pegawai semakin meningkat dengan meningkatkan kepuasan kerja dapat berdampak pada kinerja pegawai semakin meningkat pula. Disiplin kerja yang semakin baik akan meningkatkan kepuasan kerja bagi pegawai Kantor Pelayanan Perbendaharaan Negara Padang, karena pegawai terhindar dari masalah-masalah sanksi sosial sehingga kerja menjadi lebih baik.

Bedasarkan penjelasan diatas, hipotesis yang diajukan peneliti yang akan dibuktikan secara empiris sebagai berikut:

$\mathrm{H}_{2}$ : Pengaruh yang positif disiplin kerja terhadap kepuasan kerja

\section{METODE PENELITIAN}

\subsection{Data dan Sampel}

Metode penelitian ini menggunakan metode kuantitatif. Objek penelitian dilakukan di Kantor Pelayanan Perbendaharaan Negara Padang yang beralamat di jalan Perintis Kemerdekaan No. 79 Kelurahaan Jati Baru, Kecamatan Padang Timur Kota Padang. Dalam penelitian ini yang menjadi populasi adalah semua pegawai Kantor Kantor Pelayanan Perbendaharaan Negara Padang yang berjumlah sebanyak 40 orang pegawai.Teknik pengambilan sampel yang digunakan dalam penelitian ini adalah teknik total sampling, dengan mengambil semua pegawai sebagai responden dimana jumlah penelitian sampel sebanyak 40 pegawai.

\subsection{Definisi Operasional Variabel}

Definisi operasional dan indikator dari setiap variabel penelitian dikemukakan pada tabel berikut ini. 
Tabel 2.1 Variabel, Defenisi Dan Indikator Penelitian

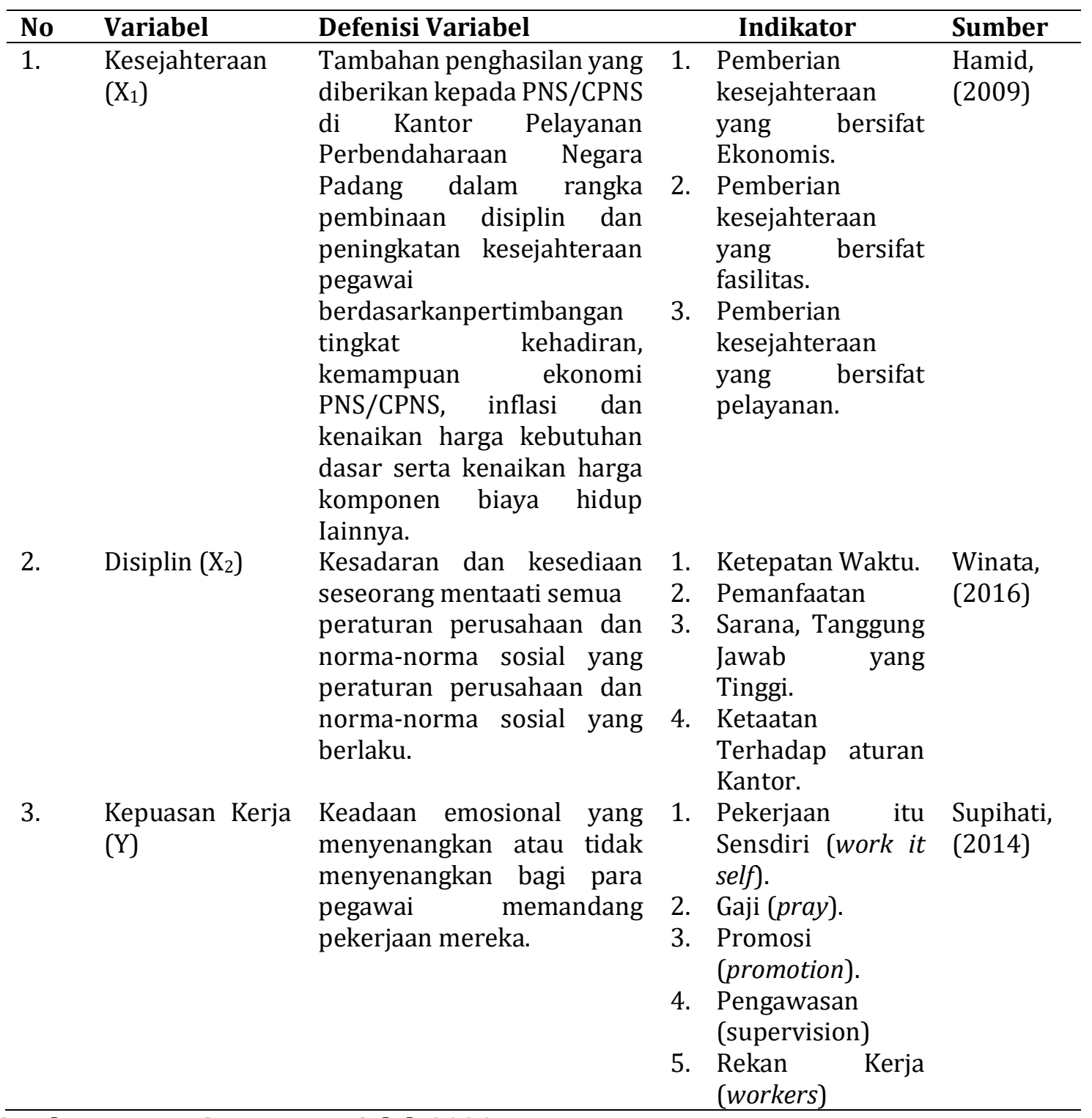

Sumber: Data Primer Yang Diolah 2021

\subsection{Analisis Regresi Linear Berganda}

\section{Persamaan Regresi Linear Beganda}

$\mathrm{Y}=\alpha+\beta_{1} X_{1}+\beta_{2} X_{2}+e$

Keterangan $=\mathrm{Y}:$ Kepuasan, $\alpha$ : Alpha, $\beta_{1}:$ Koefisien regresi Kesejahteraan, $\beta_{2}$ :

Koefisien regresi Disiplin, $\mathrm{X}_{1}$ : Variabel Kesejahteraan, $\mathrm{X}_{2}$ : Variabel Disiplin, e :

kesalahan (error). 


\section{HASIL PENELITIAN}

\subsection{Uji Validitas}

Uji validitas digunakan untuk mengetahui sah atau tidak data kuesioner. Dalam penelitian ini pengujian validitas dari semua variabel menggunakan program SPSS 16, hasil output program SPSS ini di dapat semua variabel penelitian ialah Keseahteraan, Disiplin kerja, dan Kepuasan kerja dinyatakan valid.

Tabel 3.1 Uji Validitas Kesejahteraan Pegawai ( $\left.\mathrm{X}_{1}\right)$

\begin{tabular}{llll}
\hline \multicolumn{1}{c}{ Item Pertanyaan } & $\begin{array}{c}\text { Corrected Item- } \\
\text { Total Correlation }\end{array}$ & R-Tabel & Keterangan \\
\hline Item X1.P1 & 0,820 & 0,312 & Valid \\
Item X1.P2 & 0,777 & 0,312 & Valid \\
Item X1.P3 & 0,562 & 0,312 & Valid \\
Item X1.P4 & 0,789 & 0,312 & Valid \\
Item X1.P5 & 0,834 & 0,312 & Valid \\
Item X1.P6 & 0,727 & 0,312 & Valid \\
Item X1.P7 & 0,918 & 0,312 & Valid \\
Item X1.P8 & 0,800 & 0,312 & Valid \\
Item X1.P9 & 0,687 & 0,312 & Valid \\
Item X1.P10 & 0,884 & 0,312 & Valid \\
\hline
\end{tabular}

Sumber : Data Olahan SPSS 16 ( Data Diolah Tahun 2021)

Dari tabel 3.1 diatas maka dapat ditarik kesimpulan bahwa dari 10 item pertanyaan variabel kesejahteraan pegawai dikatakan valid adalah sebanyak 10 karena Corrected Item Total Correlation dari pertanyaan tersebut $\mathrm{r}$ hitung $>$ r table sehingga dapat digunakan untuk penelitian lebih lanjut.

Tabel 3.2 Uji Validitas Disiplin Kerja $\left(\mathrm{X}_{2}\right)$

\begin{tabular}{llll}
\hline \multicolumn{1}{c}{ Item Pertanyaan } & $\begin{array}{c}\text { Corrected Item-Total } \\
\text { Correlation }\end{array}$ & R-Tabel & Keterangan \\
\hline Item X2.P1 & 0,898 & 0,312 & Valid \\
Item X2.P2 & 0,864 & 0,312 & Valid \\
Item X2.P3 & 0,882 & 0,312 & Valid \\
Item X2.P4 & 0,860 & 0,312 & Valid \\
Item X2.P5 & 0,913 & 0,312 & Valid \\
Item X2.P6 & 0,903 & 0,312 & Valid \\
Item X2.P7 & 0,785 & 0,312 & Valid \\
Item X2.P8 & 0,855 & 0,312 & Valid \\
Item X2.P9 & 0,855 & 0,312 & Valid \\
\hline
\end{tabular}

Sumber : Data Olahan SPSS 16 ( Data Diolah Tahun 2021)

Dari tabel 3.2 diatas maka dapat ditarik kesimpulan bahwa dari 9 item pertanyaan variabel disiplin kerja dikatakan valid adalah sebanyak 9 karena 
corrected item total correlation dari pertanyaan tersebut $r$ hitung $>r$ table sehingga dapat digunakan untuk penelitian lebih lanjut.

Tabel 3.3 Uji Validitas Kepuasan Kerja (Y)

\begin{tabular}{llll}
\hline $\begin{array}{c}\text { Item } \\
\text { Pernyataan }\end{array}$ & $\begin{array}{c}\text { Corrected Item- } \\
\text { Total Correlation }\end{array}$ & R-Tabel & Keterangan \\
\hline Item Y.P1 & 0,872 & 0,312 & Valid \\
Item Y.P2 & 0,851 & 0,312 & Valid \\
Item Y.P3 & 0,881 & 0,312 & Valid \\
Item Y.P4 & 0,813 & 0,312 & Valid \\
Item Y.P5 & 0,890 & 0,312 & Valid \\
Item Y.P6 & 0,940 & 0,312 & Valid \\
Item Y.P7 & 0,873 & 0,312 & Valid \\
Item Y.P8 & 0,921 & 0,312 & Valid \\
Item Y.P9 & 0,924 & 0,312 & Valid \\
Item Y.P10 & 0,776 & 0,312 & Valid \\
\hline
\end{tabular}

Sumber : Data Olahan SPSS 16 ( Data Diolah Tahun 2021)

Dari tabel 3.3 diatas maka dapat ditarik kesimpulan bahwa dari 10 item pertanyaan variabel kepuasan kerja dikatakan valid adalah sebanyak 10 karena corrected item total correlation dari pertanyaan tersebut $r$ hitung $>r$ table sehingga dapat digunakan untuk penelitian lebih lanjut.

\subsection{Uji Validitas}

Tabel 3.4 Reliablitias

\begin{tabular}{llll}
\hline \multicolumn{1}{c}{ Variabel } & Cronbach's Alpha & $\begin{array}{c}\text { Standar } \\
\text { Pengukuran }\end{array}$ & Keterangan \\
\hline Kesejahteraan & 0,924 & 0,60 & Realiabel \\
Pegawai & 0,958 & 0,60 & Realiabel \\
Disiplin Kerja & 0,962 & 0,60 & Realiabel \\
Kepuasan Kerja &
\end{tabular}

Sumber : Data Olahan SPSS 16 ( Data Diolah Tahun 2021)

Dalam penelitian ini pengujian reliabilitas"dari semua variabel yang menggunakan program SPSS 16,"dari perolehan output program SPSS tersebut didapat hasil semua variabel dinyatakan reliabel.

\subsection{Uji Normalitas}

Metode yang dilakukan adalah uji one sample kolmogorof-smirnov dengan uji SPSS 16, dan di dapat hasil dari output SPSS 16 ini adalah hasil signifikansi dari uji normalitas sebesar 0,715 dimana hasilnya lebih besar dari taraf sinifikansi 0,05 . Sehingga dapat dihasilkan uji tes normalitas pada penelitian adalah terdistribusi normal. 
Tabel 3.5 Uji Normalitas

\begin{tabular}{lcc}
\hline \multicolumn{1}{c}{ Indikator } & Nilai & Kesimpulan \\
\hline Kolmogorov-Smirnov Z & 0,698 & Model terdistribusi \\
Asymp. Sig. (2-tailed) & 0,715 & normal \\
\hline
\end{tabular}

Sumber : Data Olahan SPSS 16 ( Data Diolah Tahun 2021)

\subsection{Uji Multikolinearitas}

Tabel 3.6 Uji Multikolinearitas

\begin{tabular}{cccc}
\hline Variabel & Tolerance & VIF & Kesimpulan \\
\hline Kesejahteraan Pegawai $\left(\mathrm{X}_{1}\right)$ & 0,319 & 3,13 & Bebas gejala Multikollinearitas \\
Disiplin kerja $\left(\mathrm{X}_{2}\right)$ & 0,319 & 3,13 & Bebas gejala Multikollinearitas \\
\hline
\end{tabular}

Sumber : Data Olahan SPSS 16 ( Data Diolah Tahun 2021)

Hasil Uji Multikolinieritas Penelitian ini menggunakan alat bantu SPSS 16 dalam mengolah data penelitian, dari hasil output SPSS 16 didapatkan hasil perhitungan table hasil uji multikollinearitas. Nilai variabel bebas VIF $=3,130$ dimana nilai tersebut lebih kecil dari 10. Dapat disimpulkan bebas dari multikollinearitas.

\subsection{Uji Heteroskedastisitas}

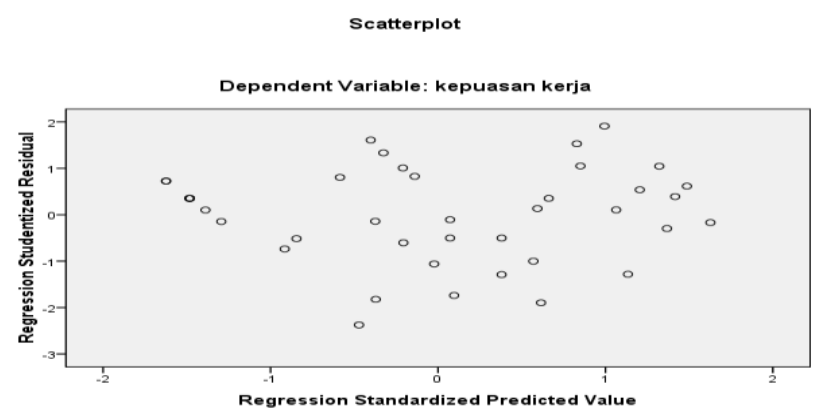

Gambar 3.1 Hasil Uji Heteroskedastisitas

Sumber: Data Olahan SPSS 16 (data diolah tahun 2021)

Dari gambar 1 diatas dilihat bahwa adanya penyebaran titik atau lingkaran regression satandardized predicted value yang tidak membentuk satu pola tertentu seperti garis jadi dapat dirumskan bahwa variabel yang di uji tidak memiliki gejala heteroskedastitasitas sehingga penelitian dapat dilanjutkan. 


\subsection{Uji Regresi Linear Berganda}

\section{Tabel 3.7 Uji Regresi Linear Berganda}

\begin{tabular}{ll}
\hline Variabel & Koefisien/Parameter \\
\hline (Constant) & $-1,286$ \\
Kesejahteraan Pegawai $\left(\mathrm{X}_{1}\right)$ & 0,458 \\
Disiplin Kerja $\left(\mathrm{X}_{2}\right)$ & 0,617 \\
\hline
\end{tabular}

Sumber: Data Olahan SPSS 16 (data diolah tahun 2021)

Berdasarkan uji data menggunakan spss 16, terdapat hasil persamaan regresi sebagai berikut:

$Y=-1,286+0,458 X_{1}+0,617 X_{2}$

Persamaan regresi diatas menampilkan variabel independent dengan variabel dependent secara parsial, dari persamaan tersebut dapat disimpukan sebagai berikut :

1. Nilai konstansta sebesar $-1,286$ artinya jika tidak terjadi perubahan variabel kesejahteraan pegawai $\left(\mathrm{X}_{1}\right)$ dan disiplin kerja $\left(\mathrm{X}_{2}\right)$ diasumsikan $\mathrm{X}_{1}$ Dan $\mathrm{X}_{2}$ bernilai 0 , maka kepuasan pegawai pada Kantor Pelayanan Perbendaharaan Negara Padang adalah sebesar -1,286 satuan.

2. Nilai koefisien regresi kesejahteraan pegawai adalah 0,458 , artinya jika variabel kesejahteraan pegawai $\left(\mathrm{X}_{1}\right)$ meningkat sebesar $1 \%$ atau 1 satuan dengan asumsi variabel disiplin kerja $\left(\mathrm{X}_{2}\right)$ dan konstansta (a) adalah 0 (nol), maka kepuasan pegawai pada kantor pelayanan perbendaharaan Negara padang meningkat sebesar $1 \%$ atau 1 satuan. Hal tersebut melihatkan bahwa variabel kesejahteraan pegawai yang diberikan berkontribusi positif bagi kepuasan pegawai, sehingga makin komplit kesejahteraan pegawai yang diberikan di Kantor Pelayanan Perbendaharaan Negara Padang, semakin meningkat pula tingkat kepuasan pegawai yang dirasakan.

3. Nilai koefisien regresi disiplin kerja ialah 0,617 artinya jika variabel disiplin kerja $\left(\mathrm{X}_{2}\right)$ meningkat sebesar $1 \%$ atau 1 satuan dengan asumsi variabel kesejahteraan pegawai $\left(\mathrm{X}_{1}\right)$ dan konsttanta (a) adalah 0 (nol), maka kepuasan pegawai pada Kantor Pelayanan Perbendaharaan Negara Padang menigkat sebesar $1 \%$ atau 1 satuan. Hal tersebut menerangkan disiplin kerja yang diberikan berkontribusi positif bagi kepuasan 
Pengaruh Pemberian Kesejahteraan Pegawai Dan Disiplin Kerja Terhadap Kepuasan Kerja Di Lingkungan Kantor Pelayanan Perbendaharaan Negara Padang

pegawai, sehingga makin besar disiplin kerja, maka makin meningkat pula kepuasan yang pegawai rasakan.

\subsection{Uji Hipotesis ( Uji T)}

Uji hipotesis ini bertujuan untuk melihat pengaruh variabel independen tehadap variabel dependen secara parsial, instrumen yang digunakan yaitu SPSS 16 dan didapat output seperti terlihat pada tabel dibawah ini:

Tabel 3.8 Hasil Uji T

\begin{tabular}{llll}
\hline Variabel & t_hit & Sig & Kesimpulan \\
\hline Kesejahteraan Pegawai & 3,946 & 0,000 & H1 diterima \\
Disiplin Kerja & 5,368 & 0,000 & H2 diterima \\
\hline
\end{tabular}

Sumber: Data Olahan SPSS 16 (data diolah tahun 2021)

\section{Pengaruh Variabel Kesejahteraan Pegawai $\left(\mathrm{H}_{1}\right)$}

Variabel kesejahteraan pegawai $\left(\mathrm{X}_{1}\right)$ berpengaruh secara positif dan signifikan terhadap kepuasan pegawai pada Kantor Pelayanan Perbendaharaan Negara Padang. Hal ini terlihat dari signifikan kesejahteraan pegawai $\left(\mathrm{X}_{1}\right) 0,000<0,05$, dan nilai $\mathrm{t}$ table $=\mathrm{t}(\mathrm{a} / 2 ; \mathrm{n}-\mathrm{k}-1=\mathrm{t}(0,05 / 2 ; 40-2-1)=$ $(0,025 ; 37)=2,026$. Bearti nilai thitung lebih besar dari t table $(3,946>2,026)$. maka H0 ditolak H1 diterima. Sehingga hipotesis yang berbunyi terdapat pengaruh kesejahteraan pegawai terhadap kepuasan pegawai secara parsial diterima.

\section{Pengaruh Variabel Disiplin Kerja $\left(\mathrm{H}_{2}\right)$}

Variabel disiplin kerja $\left(\mathrm{X}_{2}\right)$ berpengaruh secara positif dan signifikan terhadap kepuasan pegawai pada Kantor Pelayanan Perbendaharaan Negara Padang. Hal ini terlihat dari signifikan kesejahteraan pegawai $\left(\mathrm{X}_{2}\right) 0,000<0,05$, dan nilai $\mathrm{t}$ table $=\mathrm{t}(\mathrm{a} / 2 ; \mathrm{n}-\mathrm{k}-1=\mathrm{t}(0,05 / 2 ; 40-2-1)=(0,025 ; 37)=2,026$. Bearti nilai t hitung lebih besar dari t table $(5,386>2,026)$. maka H0 ditolak H2 diterima. Sehingga hipotesis yang berbunyi terdapat pengaruh kesejaht

\subsection{Uji Hipotesis ( Uji F)}

Uji hipotesis bertujuan untuk mengetahui pengaruh variabel independen secara simultan terhadap variabel dependen, instrumen yang dipakai yaitu SPSS 16 dan output dari uji ini dapat dilihat pada tabel dibawah ini: 
Pengaruh Pemberian Kesejahteraan Pegawai Dan Disiplin Kerja Terhadap Kepuasan Kerja Di Lingkungan Kantor Pelayanan Perbendaharaan Negara Padang

Tabel 3.9 Hasil Uji F

\begin{tabular}{llll}
\hline Model & F & Sig & Kesimpulan \\
\hline Simultan & 124,166 & 0,000 & H3 Diterima \\
\hline
\end{tabular}

Sumber: Data Olahan SPSS 16 (data diolah tahun 2021)

Dari hasil pengujian pada tabel diatas dapat diketahui pada nilai $\mathrm{F}$ hitung sebsesar 124,166 dengan nilai $\mathrm{F}$ table 3,230 sehingga nilai $\mathrm{F}$ hitung $>\mathrm{F}$ table atau 124,166 > 3,230, dan tingkat signifikan 0,000 < 0,05 maka $\mathrm{H}_{1}$ diterima dan $\mathrm{H}_{2}$ diterima, dapat disimpulkan variabel kesejahteraan pegawai $\left(\mathrm{X}_{1}\right)$ dan disiplin kerja $\left(\mathrm{X}_{2}\right)$ secara bersamaan berpengaruh signifikan terhadap kepuasan pegawai pada Kantor pelayanan Perbendaharaan Negara Padang.

\section{PEMBAHASAN}

\subsection{Pengaruh Pemberian Kesejahteraan Pegawai Terhadap Kepuasan Kerja di Kantor Pelayanan Perbendaharaan Negara Padang.}

Kesejahteraan adalah "keadaan dimana seseorang merasakan adanya ketentraman (kesejahteraan batin) dan kemakmuran (kesejahteraan lahir)" (M. Busro, 2018). Kesejahteraan lahir dapat dicapai karena ada upah kepemilikan tempat tinggal yang berkualitas, perabotan rumah yang berkualitas, sarana hiburan, saran transportasi, dan kepemilikan asset. Kesejahteraan batin dapat dicapai melalui penerimaan diri, hubungan yang positif dengan orang lain, dan pertumbuhan pribadi.

Hasil yang telah didapat bahwa pemberian kesejahteraan pegawai berpengaruh signifikan dan positif terhadap kepuasan kerja. Berdasarkan uji t menunjukan bahwa pemberian kesejahteraan berpengaruh signifikan dan positif terhadap kepuasan kerja dilingkungan kantor pelayanan perbendaharaan Negara padang. Maka dapat disimpulkan bahwa hipotesis pertama diterima. Hal ini sama dengan penelitian Makutika et al, (2018), Hasibuan et al, (2019), dan Harto et al, (2015), Pengaruh yang positif dan signifikan antara pemberian kesejahteraan pegawai terhadap kepuasan kerja. Berdasarkan beberapa pendapat dapat disimpulkan bahwa pemberian kesejahteraan pegawai adalah balas jasa tidak langsung atau imbalan diluar gaji atau upah yang diberikan kepada pegawai dan pemberiannya tidak didasarkan kinerja pegawai tetapi berdasarkan pada keanggotaannya 
sebagai bagian dari organisasi yang berguna untuk memenuhi kebutuhan pegawai diluar upah/gaji.

Kesimpulan dari penelitian-penelitian sebelumnya bahwa kesejahteraan pegawai menjadi keinginan setiap orang karena dengan hidup sejahtera orang akan dapat menikmati hidupnya. Demikian juga dengan pegawai disuatu perusahaan/instansi, jika kesejahteraan pegawai itu terjamin maka akan dapat meningkatkan prestasi kerja pegawai. Kesejahteraan pegawai merupakan tunjangan diluar gaji sehingga dilihat dari bentuk indikator kesejahteraan yang bersifat ekonomis sama halnya dengan dilingkungan Kantor Pelayanan Perbendaharaan Negara Padang bahwa kesejahteraan pegawai yang diberikan merupakan tunjangan di luar gaji, hal ini sangat membantu bagi para pegawai.

\subsection{Pengaruh Disiplin Kerja Terhadap Kepuasan kerja}

Kedisiplinan adalah "perhatian dan keinginan individu untuk mematuhi semua kontrol perusahaan dan norma-norma sosial yang berlaku" (Abdurrahmat, 2006). Kesadaran merupakan "sikap seseorang yang dengan sengaja mematuhi semua aturan dan memperhatikan kewajiban dan tanggung jawabnya '. Semangat adalah sikap, perilaku dan aktivitas seseorang dalam memahami kendali perusahaan, baik tenang maupun tidak.

Hasil telah didapat bahwa disiplin kerja berpengaruh signifikan dan positif terhadap kepuasan kerja. Berdasarkan uji t menunjukan bahwa disiplin kerja berpengaruh signifikan dan positif terhadap kepuasan kerja dilingkungan kantor pelayanan perbendaharaan Negara padang. Maka dapat disimpulkan bahwa hipotesis kedua diterima. Sesuai dengan penelitian Afianto \& Utami, (2017), Wuysang \& Tawas, (2016), Pratama et al, (2020), Pengaruh yang positif dan signifikan antara Disiplin kerja terhadap kepuasan kerja. Berdasarkan beberapa pendapat dapat disimpulkan bahwa semakin baik disiplin kerja maka semakin tinggi kepuasan kerja pegawai, begitupun sebaliknya semakin buruk disiplin kerja maka semakin turun kepuasan pegawai terhadap pekerjaannya.

Kesimpulannya dari penelitian-penelitian sebelumnya bahwa hasil ini mengindikasikan bahwa meningkatnya disiplin kerja yang disebabkan oleh 
Pengaruh Pemberian Kesejahteraan Pegawai Dan Disiplin Kerja Terhadap Kepuasan Kerja Di Lingkungan Kantor Pelayanan Perbendaharaan Negara Padang

kehadiran pegawai yang tepat waktu, tidak pernah pulang sebelum jam kerja selesai, mampu menggunakan waktu secara efektif, vekerja dengan kualitas kerja yang baik, mengikuti prosedur da intruksi kerja dari atasan, hadir dalam setiap rapat dan berpenampilan sopasn dan berpakaian sesuai aturan yang ada maka dapat menyebabkan keputusan kerja pegawai semakin meningkat dengan meningkatkan kepuasan kerja dapat berdampak pada kinerja pegawai semakin meningkat pula. Disiplin kerja yang semakin baik akan meningkatkan kepuasan kerja bagi pegawai Kantor Pelayanan Perbendaharaan Negara Padang, karena pegawai terhindar dari masalah-masalah sanksi sosial sehingga kerja menjadi lebih baik.

\section{KESIMPULAN}

Berdasarkan hasil penelitian oleh penulis maka menghasilkan kesimpulan sebagai berikut :

1. Secara parsial, pemberian kesejahteraan pegawai berpengaruh signifikan dan positif terhadap kepuasan kerja di lingkungan kantor pelayanan perbendahraan negara padang.

2. Secara parsial, disiplin kerja berpengaruh signifikan dan positif terhadap kepuasan kerja di lingkungan kantor pelayanan perbendahraan Negara padang.

\section{REFERENSI}

Abdurrahmat, F. (2006). Organisasi Dan Manajemen Sumber Daya manusia (ke1).

Afianto, I. D., \& Utami, H. N. (2017). Pengaruh Disiplin Kerja dan Komunikasi Organisasi Terhadap Kepuasan Kerja dan Kinerja Karyawan (Studi pada Karyawan Divisi Marketing PT. Victory International Futures Kota Malang). Jurnal Administrasi Bisnis S1 Universitas Brawijaya, 50(6), 58-67.

Almeida, N., \& Perera, G. (2015). The Impact of Welfare on Job Satisfaction among Non Managerial Employees in the Apparel Industry in Sri Lanka. Proceedings of International HR Conference, 2(1), 109-115. http://journals.sjp.ac.lk/index.php/phrc/article/view/2889

Busro, M. (2018). Teori-teori Manajemen Sumber Daya Manusia. Manajemen Sumber Daya Manusia.

Hamid, M. S. F. (2009). Identifikasi Kompetensi Karyawan Yang Mempengaruhi Pencapaian Kinerja Bidang Produksi Di Pt. Industri Sandang Nusantara (Persero) Dengan Pemberian Insentif Sebagai Variabel Moderator. In Management. 
Harto, M. A., Fathoni, A., \& H, L. B. (2015). Pengaruh Gaya Kepemimpinan, Budaya Kaizen Dan Kesejahteraan Terhadap Kepuasan Kerja Karyawan ( studi empiris di PT. Techkpack Asia Demak ). Jurnal Ekonomika Dan Bisnis, 2.

Hasibuan, D., Safitri, H., \& Hendry, R. S. M. (2019). Pengaruh Kesejahteraan Dan Desain Pekerjaan Terhadap Kepuasan Kerja Pada Pt. Perkebunan Nusantera Iii (Persero) Pks Torgamba Kabupaten Labuhanbatu Selatan. Jurnal Ekonomi Bisnis Manajemen Akuntansi, 1(1), 17-23.

Lantara, I., \& Utama, I. (2014). Pengaruh Insentif Finansial, Insentif Non Finansial dan Lingkungan Kerja terhadap Kepuasan Kerja Karyawan pada PT. Tiara Cipta Nirwana. E-Jurnal Manajemen Universitas Udayana.

Makutika, D. H. P., Adolfina, \& Uhing, Y. (2018). Pengaruh Kepemimpinan, Kesejahteraan dan Komunikasi terhadap Kepuasan kerja karyawan pada PT. Bank Sulutgo Cabang Tahuna. Jurnal EMBA, 6(4), 3473-3482.

Pratama, R., Wahjusaputri, S., \& Wibowo, A. A. (2020). Pengaruh Disiplin Kerja Dan Budaya Organisasi Terhadap Kepuasan Kerja Karyawan Pizza Hut Jakarta Timur. Riset Manajemen, 7(1), 105-112.

Sajangbati, I. A. . (2013). Motivasi, Disiplin, Dan Kepuasan Pengaruhnya Terhadap Kinerja Pegawai Pt. Pos Indonesia (Persero) Cabang Bitung. Jurnal EMBA: Jurnal Riset Ekonomi, Manajemen, Bisnis Dan Akuntansi, 1(4), 667-678.

Singodimedjo. (2009). Manajemen Sumber Daya Manusia. In Manajemen Sumber Daya Manusia.

Supihati, S. (2014). Analisis Faktor-faktor Yang Mempengaruhi Kinerja Karyawan Perusahaan Sari Jati Di Sragen. Jurnal Paradigma Universitas Islam Batik Surakarta.

Winata. (2016). Pengaruh Kepuasan Kerja dan Kompensasi terhadap Kinerja Karyawan pada Hotel Inna Dharma Deli Medan. Jurnal Ilman.

Wuysang, P. E. B., \& Tawas, H. N. (2016). Pengaruh Disiplin Kerja, Perilaku Kepemimpinan Dan Motivasi Kerja Terhadap Kepuasan Kerja Dan Prestasi Kerja Karyawan Kfc Bahu Mall Manado. Jurnal Berkala Ilmiah Efisiensi, 16(01), 375-388. 